\title{
BACTERIAL QUALITY OF RAINWATER IN SELECTED COMMUNITIES IN IMO STATE, NIGERIA
}

\author{
Avaliação bacteriana das águas das chuvas em comunidades \\ do estado de Imo, Nigéria
}

Okereke, J. N. *1

Obasi, K. O. ${ }^{1}$

Obiekezie, S. O. ${ }^{1}$

Okechukwu R. I. ${ }^{1}$

\section{Abstract}

Many rural communities in Imo State, Eastern Nigeria do not have access to potable water. Rainwater has been a major source of water supply in these areas mainly during the rains. Bacterial quality of harvested rainwater from three communities (Umunumo, Egbema, Ihiagwa) were determined. Rainwater samples were harvested directly, from zinc roof, thatched roof and from asbestos roof, at different periods of the rains - May (beginning of rains), July (peak of rain) and October (end of rains). Stored rainwater from zinc roof in Umunumo was also examined. The bacterial count was high at the beginning of rains with rainwater collected from thatched roof in Egbema showing the highest $\left(7.4 \times 10^{3} \mathrm{cfu} / 100 \mathrm{ml}\right)$ value. The total coliform and faecal coliform (Escherichia coli) counts ranged highest at the beginning of rains between $10-36 \mathrm{cfu} /$ $100 \mathrm{ml}$ and $1-5 \mathrm{cfu} / 100 \mathrm{ml}$ respectively. The total bacterial counts, total coliform counts and faecal coliform counts of stored rainwater were highest in samples from underground tank. Samples collected directly at the peak and end of rains in all the communities met the WHO standard for drinking water. Using a statistical model, at a $=0.05$, the null hypothesis, was rejected for methods and period of collection, while location of collection was accepted, hence only period and method of collection of rainwater affected the bacterial quality.

Keywords: Bacterial quality; Coliforms; Contamination; Handling; Harvesting; Potable; Rainwater; Waterborne.

${ }^{1}$ Department of Biotechnology, Federal University of Technology, Owerri, Nigeria

* Corresponding Author; E-mail:chinwendubueze@yahoo.com 


\section{Resumo}

Muitas comunidades rurais do estado de Imo, Nigéria oriental, não têm acesso à água potável, sendo que a água da chuva tem sido sua principal fonte. Neste estudo, foram determinados os níveis bacterianos da água da chuva em três comunidades, Umunumo, Egbema e Ihiagwa. As amostras foram colhidas diretamente de telhados de zinco, telhados de sapê e telhados de amianto em diferentes períodos de chuva, mês de maio (começo das chuvas), mês de julho (pico das chuvas) e outubro (final das chuvas). A água acumulada de telhados de zinco da comunidade de Umunumo também foi examinada. O nível bacteriano foi alto no começo das chuvas nas amostras coletadas nos telhados de sapê, sendo seu maior valor em Egbema $\left(7,4 \times 10^{3} \mathrm{cfu} / 100 \mathrm{ml}\right)$. Os níveis de coliformes totais e coliformes fecais (Escherichia coli) tiveram picos no começo das chuvas, 10 - $36 \mathrm{cfu} / 100 \mathrm{ml}$ e $1-5 \mathrm{cfu} / 100 \mathrm{ml}$, respectivamente. Também nos reservatórios subterrâneos a contagem total de bactérias, coliformes totais e coliformes fecais totais foi muito elevada. As amostras estudadas dos meses de julho (pico) e outubro (final) de todas as comunidades estavam dentro do padrão de qualidade de água potável da OMS. Usando um modelo estatístico (para a = 0.05), a hipótese nula foi rejeitada para os métodos e o período da coleta, enquanto que o local de coleta foi aceito. Portanto, apenas o período e o método de coleta das águas das chuvas afetam os níveis bacterianos. Palavras-chave: Qualidade bacteriana; Coliformes; Contaminação; Manuseio; Colheita; Potabilidade; Chuva; Reservatório de água.

\section{Introduction}

Rainwater harvesting (RWH) has become a global practice in order to meet the growing challenges of water supply. Many countries of the world have adopted rainwater as a major alternative water supply since underground and surface water bodies are under pressure of industrial pollution.

Imo State in Eastern Nigeria has a large population of more than 7 million people with more than $70 \%$ of the entire populace living in rural areas where there are no supply of pipeborne water. In the urban areas where portable water supply is epileptic, people resort to rainwater mainly during the rains. A mean intensity of $180-220 \mathrm{~cm}$ of rainfall is experienced in the Southern part of Nigeria (1). No source of water supply for human consumption can be assumed to be free from pollution. However, rainwater, if well handled, is the purest natural water (2). Both natural and anthropological pollution affect water quality (3). Polluted water has been important vehicle for the spread of diseases. It has been estimated that about 50,000 people die daily world-wide as a result of water-borne diseases (4).

Many rural communities in Imo state practice domestic roof rainwater harvesting (DRWH). This is done between May to October each year with underground and surface tanks serving as storage facilities. Rainwater harvested from zinc and Aluminum roofs serve as drinking water without further treatment in many rural areas in Imo State while water from thatched roofs is used for other domestic purposes, but serve as drinking water in some homes in Botswana (5). This may lead to diseases as poor water quality is considered a major cause of water-borne diseases in remote areas (6). This study was aimed at examining the bacterial quality of rainwater, a major source of water supply in many rural communities in Imo State, Nigeria with the view of evaluating its health implications.

\section{Materials and Methods}

\section{Sample Collection}

Rainwater samples used for this study were harvested from different communities in Imo State, Nigeria designated A, B and C.

The samples were tagged accordingly:

SA - Samples from Egbema, Orlu Zone

SB - Samples from Umunumo, Okigwe

Zone

SC - Samples from Ihiagwa, Owerri Zone

SD1, SD2, SD3 represent samples from PVC water tank, metallic water tank and underground water tank respectively.

\section{Method of Collection}

Rainwater samples were collected directly (1), from zinc roofs (2) thatched roofs (3) or asbestos roofs (4). 


\section{Period of Collection}

Samples were collected at different periods of the rains: beginning of rains (May), peak of rains (July), and end of rains (October), using sterile $5 \mathrm{dm}^{3}$ plastic basins, and transferred to $2 \mathrm{dm}^{3}$ plastic bottles using sterile funnels.

\section{Microbiological Analyses}

Microbiological Analyses were conducted within 6 hours of collection.

Total Bacterial Counts: The pour plate method using nutrient agar was used. Plates were prepared in duplicates and incubated at $37^{\circ} \mathrm{C}$ for $48 \mathrm{hrs}$. The numbers of colonies were counted and the colony forming units per $100 \mathrm{ml}$ (cfu/100ml) determined.

Total Coliform Counts: Coliform counts of the samples were determined using membrane filtration technique which used absorbent pads saturated with MacConkey broth in Petri dishes prepared in duplicates and labeled correctly. The membranes were incubated at different temperatures of $37^{\circ} \mathrm{C}$ and $44^{\circ} \mathrm{C}$ for $24 \mathrm{hrs}$ for presumptive coliform count and faecal coliform (Escherichia coli) count respectively.

\section{Statistical Analysis}

The goodness of fit which used chi-square was employed because of the nature of data generated. The null hypothesis assumed that bacterial load of rainwater is not affected by: location (place), period (time), as well as, method (mode) of harvest. In each case, if the chi-square table was highly significant, at 99.95\% confidence interval, the null hypothesis was accepted, otherwise rejection of the null hypothesis.

\section{Results}

The bacterial count of rainwater harvested at the beginning of rains show that total bacterial count was of the order $10^{3}$, ranging from $0.39 \times 10^{3}-7 \times 10^{3} \mathrm{cfu} / 100 \mathrm{ml}$.

Total coliforms observed were between 10 - $36 \mathrm{cfu} / 100 \mathrm{ml}$ while faecal coliforms ranged between 1-5cfu/100 $\mathrm{ml}$ (Table 1).

Bacterial count of rainwater harvested at the peak of rains is shown in table 2. The total bacterial count decreased and was in the order of $10^{2}$. There was reduction in total coliform count and Escherischia coli. Feacal coliforms ranged within 0 - $4 \mathrm{cfu} / 100 \mathrm{ml}$ while $E$. coli had $1.0 \mathrm{cfu} /$ $100 \mathrm{ml}$ as the highest recorded value.

The data in table 3 shows the bacterial count of rainwater at the end of rains. As at the peak, the total bacterial count was of the order $10^{2}$. Coliforms were recorded in all the samples except in SC, but in decreased number $(1-3 \mathrm{cfu} /$ $100 \mathrm{ml})$. Escherischia coli was $\leq 1.0 \mathrm{cfu} / 100 \mathrm{ml}$. The bacterial count of stored zinc-roof rainwater shows that it ranged between $1.28 \times 10^{2}$ to $2.01 \times 10^{2} \mathrm{cfu} /$ $100 \mathrm{ml}$ (Table 4). Total coliforms of 36, 41 and 97 $\mathrm{cfu} / 100 \mathrm{ml}$ were recorded in SDI, SD2 AND SD3 respectively. Only samples from under ground water tank had $1.0 \mathrm{cfu} / 100 \mathrm{ml}$ of feacal coliform (Escherichia coli).

\section{Results Statistical Analysis}

The data in tables 5, 6 and 7 show the statistical analyses of bacterial load of rainwater from different locations, harvested at different periods and by different methods respectively. In each case, the null hypothesis which stated that bacterial count of rainwater was not affected by location of collection, period, and method of collection respectively was tested using chi-square test at 99.95\% confidence interval. The null hypothesis was accepted in table 5 hence location of collection did not affect the bacterial count of rainwater. The highly significant figures rejected the other hypothesis at degree of freedom 6 and 99.95\% confidence interval. 


\section{TABLE 1: Bacterial Counts of Rainwater Harvested at the beginning of rains} (MAY)

\begin{tabular}{|ll|l|l|l|}
\hline $\begin{array}{l}\text { Method of } \\
\text { collection }\end{array}$ & $\begin{array}{l}\text { Total Bacterial Counts } \\
(\mathbf{c f u} / \mathbf{1 0 0 m}) \mathbf{x} \mathbf{1 0}^{\mathbf{3}}\end{array}$ & $\begin{array}{l}\text { Total Coliform } \\
\text { Counts (cfu/ml) }\end{array}$ & $\begin{array}{l}\text { Faecal Coliform }(\boldsymbol{E} . \\
\text { coli) Counts } \\
\text { (cfu/ml) }\end{array}$ \\
\hline SA & 1 & 0.45 & 10 & 2 \\
& 2 & 5.00 & 19 & 3 \\
& 3 & 7.40 & 22 & 4 \\
& 4 & 4.00 & 17 & 4 \\
\hline SB & 1 & 0.39 & 14 & 3 \\
& 2 & 4.50 & 20 & 4 \\
& 3 & 6.80 & 36 & 5 \\
& 4 & 4.30 & 20 & 2 \\
\hline SC & 1 & 0.43 & 12 & 1 \\
& 2 & 4.80 & 17 & 2 \\
& 3 & 7.00 & 28 & 3 \\
& 4 & 4.40 & 21 & \\
\hline
\end{tabular}

SA: Samples from Egbema; SB:Samples from Umunumo; SC: Samples from Owerri.

TABLE 2: Bacterial Counts of Rainwater Harvested at the Peak of rains (JULY)

\begin{tabular}{|c|c|c|c|}
\hline $\begin{array}{l}\text { Method of } \\
\text { collection }\end{array}$ & $\begin{array}{l}\text { Total Bacterial Counts } \\
(\mathrm{cfu} / 100 \mathrm{ml}) \times 10^{2}\end{array}$ & $\begin{array}{l}\text { Total Coliform Counts } \\
\text { (cfu/ml) }\end{array}$ & $\begin{array}{l}\text { Faecal Coliform }(E \text {. coli) } \\
\text { Counts }(\mathrm{cfu} / \mathrm{ml})\end{array}$ \\
\hline $\begin{array}{ll}\text { SA } & 1 \\
& 2 \\
& 3 \\
& 4\end{array}$ & $\begin{array}{l}0.60 \\
1.00 \\
1.20 \\
1.07\end{array}$ & $\begin{array}{l}1 \\
3 \\
4 \\
2\end{array}$ & $\begin{array}{l}\text { nil } \\
\text { nil } \\
\text { nil } \\
\text { nil }\end{array}$ \\
\hline $\begin{array}{ll}\mathrm{SB} & 1 \\
& 2 \\
& 3 \\
& 4\end{array}$ & $\begin{array}{l}0.66 \\
1.11 \\
1.34 \\
1.06\end{array}$ & $\begin{array}{l}1 \\
2 \\
3 \\
1\end{array}$ & $\begin{array}{l}\text { nil } \\
1 \\
1 \\
\text { nil }\end{array}$ \\
\hline $\begin{array}{ll}\text { SC } & 1 \\
& 2 \\
& 3 \\
& 3 \\
& 4\end{array}$ & $\begin{array}{l}0.44 \\
1.09 \\
1.25 \\
0.92\end{array}$ & $\begin{array}{l}\text { nil } \\
1 \\
2 \\
2\end{array}$ & $\begin{array}{l}\text { nil } \\
1 \\
\text { nil } \\
1\end{array}$ \\
\hline
\end{tabular}


TABLE 3: Bacterial Counts of Rainwater Harvested at the end of rains (OCTOBER)

\begin{tabular}{|c|c|c|c|c|}
\hline \multicolumn{2}{|c|}{$\begin{array}{l}\text { Method of } \\
\text { collection }\end{array}$} & \multirow{2}{*}{$\begin{array}{l}\begin{array}{l}\text { Total Bacterial Counts } \\
\text { (cfu/100ml) } \times 10^{2}\end{array} \\
0.58\end{array}$} & \multirow{2}{*}{$\begin{array}{l}\begin{array}{l}\text { Total Coliform Counts } \\
\text { (cfu/ml) }\end{array} \\
1\end{array}$} & \multirow{2}{*}{$\begin{array}{l}\begin{array}{l}\text { Faecal Coliform (E. colit) } \\
\text { Counts (cfu/ml) }\end{array} \\
\text { nil }\end{array}$} \\
\hline SA & 1 & & & \\
\hline & 2 & 1.20 & 2 & nil \\
\hline & 3 & 1.30 & 3 & 1 \\
\hline & 4 & 1.01 & 2 & nil \\
\hline \multirow[t]{4}{*}{ SB } & 1 & 0.60 & 1 & 1 \\
\hline & 2 & 0.90 & 3 & 1 \\
\hline & 3 & 1.21 & 2 & nil \\
\hline & 4 & 0.92 & 1 & nil \\
\hline \multirow[t]{4}{*}{ SC } & 1 & 0.49 & nil & nil \\
\hline & 2 & 1.10 & 2 & nil \\
\hline & 3 & 1.31 & 2 & 1 \\
\hline & 4 & 1.02 & 1 & nil \\
\hline
\end{tabular}

TABLE 4: Bacterial Counts of Stored Rainwater from Zinc Roof

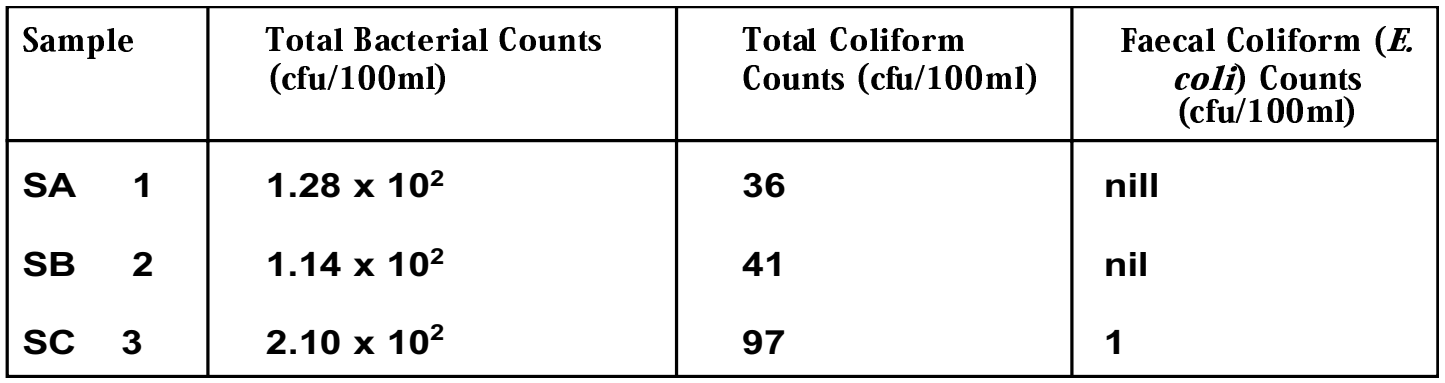


TABLE 5: Statistical Analysis of Bacterial Counts of Rainwater from Different locations.

\begin{tabular}{|c|c|c|c|c|c|}
\hline $\begin{array}{l}\text { Period of } \\
\text { collection }\end{array}$ & $\begin{array}{l}\text { Bacteria } \\
\text { (cfu/10c }\end{array}$ & Count fro & locations & & Chi-square \\
\hline & $\begin{array}{l}\text { Egbema } \\
\text { (A) }\end{array}$ & $\begin{array}{l}\text { Umunumo } \\
\text { (B) }\end{array}$ & $\begin{array}{l}\text { Ihiagwa } \\
\text { (C) }\end{array}$ & \multirow[b]{2}{*}{49450} & \\
\hline $\begin{array}{l}\text { Beginning of } \\
\text { rains }\end{array}$ & 16850 & 15990 & 16610 & & \\
\hline Peak of rains & 387 & 417 & 368 & 1172 & \\
\hline End of rains & 409 & 363 & 392 & 1164 & \\
\hline Totals & 17646 & 16770 & 17370 & 51786 & $\begin{array}{l}6.505 \\
\text { (accept) }\end{array}$ \\
\hline
\end{tabular}

Null hypothesis $\left(\mathrm{H}_{0}\right)$ : Location of harvest does not affect the bacterial counts of rainwater chi-square value at $99.95 \%$ confidence interval $(\mathrm{P}=9.488)$ at degree of freedom $(\mathrm{df})=4$

$X^{2}=\sum \frac{(O-E)^{2}}{E} s$
Where $\mathrm{O}=$ observed value, $\mathrm{E}=$ expected value

$\mathrm{E}=\frac{\text { row total } \mathrm{x} \text { column total }}{\text { Grand total }}$

$\mathrm{df}=($ Number of rows -1$) \times($ Column number -1$)$

$=(3-1) \times(3-1)=2 \times 2=4$ 
TABLE 6: Statistical Analysis of Bacterial Counts of Rainwater Harvested at Different Periods.

\begin{tabular}{|c|c|c|c|c|c|}
\hline \multirow[b]{2}{*}{$\begin{array}{l}\text { Method of } \\
\text { collection }\end{array}$} & \multicolumn{4}{|c|}{$\begin{array}{l}\text { Bacterial Counts at different } \\
\text { periods (cfu/100ml) }\end{array}$} & \multirow[b]{2}{*}{$\begin{array}{c}\text { Chi-square } \\
\qquad\left(X^{2}\right)\end{array}$} \\
\hline & $\begin{array}{l}\text { Beginning } \\
\text { of rains }\end{array}$ & $\begin{array}{l}\text { Peak of } \\
\text { rains }\end{array}$ & $\begin{array}{l}\text { End of } \\
\text { rains }\end{array}$ & Totals & \\
\hline 1 & 1250 & 170 & 167 & 1587 & \multirow{5}{*}{$\begin{array}{l}108.628 \\
\text { (reject) }\end{array}$} \\
\hline 2 & 14300 & 320 & 320 & 14940 & \\
\hline 3 & 21200 & 382 & 382 & 21938 & \\
\hline 4 & 12700 & 295 & 295 & 13298 & \\
\hline Totals & 49450 & 1149 & 1164 & 51763 & \\
\hline
\end{tabular}

Null hypothesis $\left(\mathrm{H}_{0}\right)$ : That bacterial counts of rainwater is not affected by period of harvest. Chi-square value at $99.95 \%$ confidence interval ( $P$ $=12.592$ )

$\mathrm{df}=6$

$\mathrm{X}^{2}=\sum \frac{(\mathrm{O}-\mathrm{E})^{2}}{\mathrm{E}}$
Where $0=$ observed value, $\mathrm{E}=$ expected value

$=\underline{\text { row total }} \times$ column total Grand total

$\mathrm{df}=($ Number of rows -1$) \times($ Column number -1$)$

$=(4-1) \times(3-1)=6$ 


\section{TABLE 7: Statistical Analysis of Bacterial Counts of Rainwater Collected by} Different Methods.

\begin{tabular}{|c|c|c|c|c|c|}
\hline \multirow[b]{2}{*}{$\begin{array}{l}\text { Method of } \\
\text { collection }\end{array}$} & \multicolumn{4}{|c|}{$\begin{array}{l}\text { Bacterial Counts at different periods } \\
\text { of collection } \\
\text { (cfu/100ml) }\end{array}$} & \multirow{2}{*}{$\begin{array}{l}\text { Chi-square } \\
\left(X^{2}\right)\end{array}$} \\
\hline & $\begin{array}{l}\text { Beginning of } \\
\text { rains }\end{array}$ & $\begin{array}{l}\text { Peak of } \\
\text { rains }\end{array}$ & $\begin{array}{l}\text { End of } \\
\text { rains }\end{array}$ & Totals & \\
\hline 1 & 568 & 516 & 314 & 1218 & \multirow{5}{*}{$\begin{array}{l}334.413 \\
\text { (Reject) }\end{array}$} \\
\hline 2 & 5220 & 4701 & 4519 & 1440 & \\
\hline 3 & 7650 & 7055 & 7256 & 21961 & \\
\hline 4 & 4208 & 4498 & 4592 & 13298 & \\
\hline Totals & 17696 & 16770 & 16501 & 50917 & \\
\hline
\end{tabular}

Null hypothesis $\left(\mathrm{H}_{0}\right)$ : That bacterial count of rainwater is not affected by methods of collection.

\section{Discussion and Conclusion}

The results of the bacterial quality of rainwater from selected communities in Imo State, Nigeria reveal that rainwater collected at the commencement of rains did not meet the World Health Organization (WHO) standard for drinking water. Such water however could be used for laundry and toilet flushing. The bacterial load of water determines its portability. The presence of Escherichia coli indicated faecal contamination. The rainwater at the peak and end of rains showed standard bacterial quality. The high bacterial and coliform counts in water samples at the beginning of rains is attributable to feacal contamination from humans, reptiles, birds, etc. Many investigations show that the purest form of natural water are snow and rainwater (7). The method of collection and storage however determine this attribute. The best method of collecting rainwater is the direct method since it does not come in contact with any surface except the atmosphere. However, zinc or Aluminum roof method is good, but asbestos roof should be discouraged because of Lead Solvency (8). Poor handling has been established to be the major cause of secondary contamination of rainwater $(9,10)$. Water from the underground storage tank had the highest number of both bacterial count and faecal coliforms. The reason is not far from the above affirmation - poor handling such as non-washing of the tanks before the rains, and again long storage period which could as well lead to growth of microorganisms (7).

Rainwater has served as a source of water supply in both rural and urban areas in the developed and developing countries. Since the supply of pipe-borne water to rural areas by Government in Imo State is tasky, she can device means of harnessing this naturally-purified-water by maintaining and improving its hygienic quality through proper collection and storage. Suggestions have been given that roof maintenance, screen installation, first flush devices, chlorination, boiling 
Bacterial quality of rainwater in selected communities in Imo state, Nigeria

and emptying and cleaning storage facilities at least once yearly will help in improving quality of rainwater for human consumption.

\section{References}

1 Adegbuyi SA. Rainwater Harvesting in Nigeria: Prospects and problems. A paper delivered at the $10^{\text {th }}$ International Rainwater Catechment Systems Conference, Mannheim, Germany September, 2001.

2. Arnold P. Rainwater Harvesting: The collection of rainfall and runoff in rural areas. Waterlines 1986; 4(4):74-75.

3. Cloete TE, Nevendo TS. Bacterial and chemical quality of water supply in the Dertig village settlement. Water SA 1999; 25(2):215-220.

4. Schalekamp M. The UNO-DRINKING-WATER DECADE 1980-1991: Problems and Successes. A lecture held on the occasion of the $10^{\text {th }}$ Anniversary of the Austrian Gas and Water Industry 1990.

5. Gould J. Rainwater Catchment System in Botswana. Waterlines 1994; 2(4):80-84.
6. Aleksandra P. Microbiological quality of Rainwater in selected indigenous communities in Central Australia. A paper delivered at the $10^{\text {th }}$ Int'l Rainwater Catchment system conference, Mannheim, Germany - September, 2001.

7. Water Research Commission (WRC). Guidelines on the cost effectiveness of Rural water supply and sanitation projects. Water Research Commission Report No. 231/1/93, Pretoria; 1993.

8. Jackson M H. Environmental health Reference Book. London: Butterworth-Heinemann; 1990.

9. Khon Kean University. Evaluation of Rainwater Quality: Heavy metals and Pathogens. RAINDROPS 1989; 7:7.

10. Krishna, J. H. Hygiene Techniques for Rainwater Harvesting. RAINDROPS 1992; 7:4.

Recebido em / Received: January 14, 2006. Aceito em / Accepted: March 6, 2006. 